\title{
Integration of Goods Market and Labor Market at Education Perspectives in Indonesian Agricultural Sector
}

\author{
D. Adriani \\ Agribusiness Study Program, Faculty of Agriculture \\ University of Sriwijaya (UNSRI) \\ Palembang, Indonesia \\ dessyadriani@gmail.com
}

\author{
E. Wildayana \\ Agribusiness Study Program, \\ Faculty of Agriculture University of Sriwijaya (UNSRI) \\ Palembang, Indonesia \\ wildayana.elisa@yahoo.com
}

\begin{abstract}
For Decades, Indonesia's economic growth has no impact on the more power of agricultural sector. The agricultural sector is still Characterized by subsistence, low education, low productivity, low income and underemployment. It is the caused by high dominance uneducated workforce in this sector. Hence the attention to quality and the development of human capital should be Increased in order to encourage economic growth in the agricultural sector. The purpose of this study is to analyze the economic integration of goods markets and labor markets in Indonesian agricultural sectors at the education perspective. Research methods are historical research. The Data used is secondary the data years 1977-2013 to the variable Gross Domestic Product (GDP) and employment of educated and uneducated agricultural sector. Data collected by documentation. Analysis method using Vector Error Correction Model (VECM). The results showed that the growth in GDP of agricultural sector is still up to the growth of employment both educated and uneducated; Increased employment growth in educated uneducated but declined employment. The development of the agricultural GDP and educated agricultural employment is determined by uneducated employment. There is integration between the labor market and the agricultural product market. Diminishing employment uneducated cause increasing the number of educated employment and GDP of agriculture sector.
\end{abstract}

Key words--Integration, labor market, goods market, agriculture

\section{INTRODUCTION}

Economic development is basically done to improve the welfare of society. Therefore, the majority of Indonesian people in rural areas and working in agriculture, it is logically that agricultural development a priority. During the period 1990-2014, the number of labor assorted by the agricultural sector was $48.49 \%$, while the industrial sector is only able to absorb amounted to $16.59 \%$ and the services sector was $34.92 \%$ [4]. However, it is unfortunate that the big role of the agricultural sector to absorb employment, which is the capital of Indonesia's largest, received less attention. This is one of the failure of development that has been undertaken by the government of Indonesia which has a huge impact for the low level of welfare of Indonesian farmers. The development process has given rise to the issue of disparity and injustice that weighed on the agricultural and rural sector. Economic growth in Indonesia has no impact on strengthening agricultural sector. The agricultural sector is still characterized by subsistence and low education, low productivity, low income, low savings and underemployment.

Reference [20] states that the rapid economic development is only a Necessary condition for the reduction of the unemployment rate, but it was not sufficient. Terms adequacy is improving the quality of economic growth itself. In other words, in the goods market, quality of economic growth is determined by the qualifications of the labor involved in it. Some research indicates the majority of the working age population in the agricultural sector in Indonesia have a low level of education and relatively low productivity.

Furthermore, Reference [3] states important factors that encourage the creation of employment opportunities in the job market itself is economic growth. Because labor was seen as part of the economic system, the workforce planning as a holistic approach to economic development has a very logical arguments and scientific. Reference [4] stated that the increase in labor productivity have led to economic growth while shifting the labor demand curve. Instead of labor also affects output. Reference [3] also stated that output growth depends on three important factors i.e. the quantity and quality of labor, capital goods as well as the addition of technological improvements.

In the period 1990-2013, economic growth significantly influenced negatively by the employments of agricultural sector. The negative effect of employment to economic growth becomes negative signal for the ability of the agricultural sector to create new jobs. The negative influence showed any symptoms of a decrease in productivity as a growing number of workers, as well as the theory of The Law of Diminishing Returns introduced by David Ricardo. In sector agriculture, employments are necessary to assist in the production of agricultural commodities. 
Integration, already exists between economic growth and employment also showed a negative signal for the agricultural sector's ability to create jobs. Employment as a factor of production already in the phase of decreasing returns to scale according to The Law of Diminishing Return introduced by David Ricardo. In theory, if the production process is in this phase, the use of these inputs are already excessive and should be reduced usage. It shows the workers who work in the agricultural sector has been the excess of the absorption capacity of the agricultural sector [2] [3].

Based on the above results, it is necessary to conduct further research to determine whether the negative signals also occurred on all qualifying agricultural employments. If we divide employments into educated and uneducated, then research is needed to analyze the effect of economic growth in the form of agricultural production in the goods market on the growth of educated and uneducated employments in the labor market, and vice versa. The purpose of this study is to analyze the economic integration of the goods markets and labor markets of agricultural at the perspective of education in Indonesia.

\section{FRAMEWORK AND HYPOTHESIS}

Schultz (1971) in [9] states the basic premise underlying the quality of human capital theory is the assumption that higher formal education is needed to increase the production capacity of the community. Human capital theory states that an educated population is a productive population. This theory also emphasizes the influence of education on income (earning)population. The growth rate of output exceeds the growth rate of relevant inputs (labor and capital) could be due to differences in the quality of human capital investment. Reference [25] also emphasized the importance of human capital in economic growth. The ability of a nation to adopt and implement new technologies from outside is a function of the stock of human capital it has.

Schultz theory, followed by Becker in reference [6], provides information about the quality of human capital theory as a basis in the decision for someone to improve earnings. According to Becker, there are four indicators used to declare that a human quality (human capital) of a person experiencing an increase, namely: education, training, health, and migration.

Some researchers have been able to convince other neoclassical scientifically the importance of an educated employments directly support economic growth even whole sectors of other macro-economic development. On the basis, scientific belief that the World Bank finally back to realize its international aid program to many countries. Educational contribution to economics growth becomes stronger after taking into account the effect of the interaction between education and other physical investment [15]. That is, the physical capital investment will multiply the value added in a later if at the same time, it's also made an investment of human resources, which directly will be actors and users in the physical investment.

Reference [13] also confirms the quality of investment in human capital as a factor has an important contribution to economic growth. Recent experience with venture capital to accumulate capital at a rapid rate in poor countries with regard to the quality of human capital show that if the quality of human capital investment is low, then the additional physical capital is limited.

The quality of human capital is knowledge, skills and knowledge of an employment. Thus, according to the economy (goods) conventionally, the quality of human capital is something that should be separated or valued separately [17]. Meanwhile, according to reference [11], the factors included in the quality of human capital is the level of nutrition, life expectancy, expertise, knowledge, skills and attitudes (attitudes). Both opinions are equally imposing limits that human capital is its own capital which can be equated with physical capital.

Based reference [9], three rational considerations underlying the investment decision quality of human capital, namely: (1) that the new generation should acquire part of the proper knowledge that has been acquired by the previous generation, (2) the new generation must consider how knowledge they gain is used to generate new products, processes and new social services, and (3) the population must have the courage to develop ideas, products, processes, and a new method which is the result of creative thinking.

Human resources development of a country is an essential element for the prosperity, growth and also for effective use of the resources of physical capital. Investment in human capital is an integral component of all development efforts. Education should cover a broad spectrum in the life of society itself. Development of human resources through education contributes directly to economic growth, and hence expenditure on education should be viewed as investments that productive and not merely be seen as something that the consumer without the benefit of a clear reversal (rate of return) [16].

Figure 1 shows that there is a link between the growth and the quality of human capital. Growth will result in improved quality of human capital investment, followed by an increase in demand for schools, increase capital accumulation and income gap reduction. Furthermore, capital accumulation and income distribution will boost economic growth.

Based on the above, the research hypothesis is: supposedly there is integration between the goods market and the labor market from the perspective of education in Indonesia, where (1) GDP growth in the goods market will be influenced by an increase in educated employment and declining uneducated employment, (2) Uneducated employment growth's is influenced by the increase in GDP and decrease in uneducated employment, and (3) a decrease in 
uneducated employment influenced by the increase in GDP and educated employment.

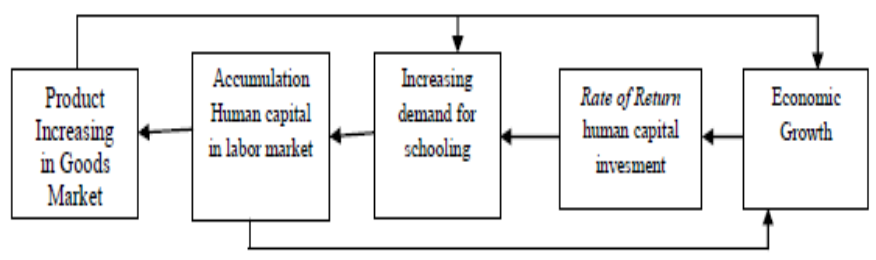

Figure 1. Research framework ( adapted from Reference [7])

\section{RESEARCH METHOD}

The research was conducted in Indonesia. This study was conducted in March 2015 to December 2015. This study uses Times Series data for 37 years from 1977-2014. The research method used is the historical research method. The data used in this study was obtained from the Central Bureau of Statistics Survey

This research model is a model that analyzes the time series data. The variables were analyzed: (1) Market Goods proxy for GDP Agriculture, and (2) labor market variables proxy for educated and uneducate empolyments in the agricultural sector. The analytical tool used is Vector Error Correction Model (VECM) to prove the integration of goods markets and labor markets based on the perspective of education in the agricultural sector of Indonesia. Data processing is done by Eviews. 9 Program.

\section{a. Stationarity Test Data}

The first step was to test and make the data becomes stationary. Test of the stationarity of data is done with the unit root test. For this purpose, Augmented DickeyFuller test (ADF) is used to determine stationary data [24].

\section{b. Determination of Optimal Lag Level}

Determination of the optimal lag length could use some criteria of the following information: (1) Akaike Information Criterion (AIC), (2) Schwarr Information Criterion (SC), (3) Likelihood Ratio (LR), and (4) adjusted $\mathrm{R}^{2}$.

\section{c. Analysis of Cointegration}

Based on Restriction VAR model with dimensions' $\mathrm{p}$ and order lag $\mathrm{k}$ (developed by reference [12].

\section{d. Specification Equation Vector Error correction model}

Reference [26], declare some variables that are not stationary at the current level, but be stationary at a difference step and cointegrated indicate a relationship or long-term balance between the variables. Models that incorporate adjustment to correct for imbalances referred is Vector Error Correction Mechanism (VECM).

VECM equation structural equations can be formulated as follows:

$$
G D P P_{t}=a_{01}+\sum_{i=1}^{p} a_{i 1} G D P P_{t-i}+\sum_{i=1}^{p} \beta_{i 1} D P T_{t-i}+\sum_{i=1}^{p} \gamma_{i 1} D P T T_{t-i}+\varepsilon_{1 t} \ldots \ldots . .(1)
$$

$$
\begin{aligned}
& D P T_{t}=a_{02}+\sum_{i=1}^{p} a_{i 2} G D P P_{t-i}+\sum_{i=1}^{p} \beta_{i 2} D P T_{t-i}+\sum_{i=1}^{p} \gamma_{i 2} D P T T_{t-i}+\varepsilon_{2 t} \ldots \ldots . .(2) \\
& D P T T_{t}=a_{03}+\sum_{i=1}^{p} a_{i 3} G D P P_{t-i}+\sum_{i=1}^{p} \beta_{i 3} D P T_{t-i}+\sum_{i=1}^{p} \gamma_{i 3} D P T T_{t-i}+\varepsilon_{3 t} \ldots . .(3)
\end{aligned}
$$

Were:

$$
\begin{aligned}
& \mathrm{DPT}_{\mathrm{ti}}=\text { Educated Employment of Agriculture } \\
& \text { sector (person/year) } \\
& \operatorname{DPT}_{(\mathrm{t}-1) \mathrm{i}}=\operatorname{Lag}_{\mathrm{DPT}} \mathrm{Di}_{\mathrm{i}} \\
& \text { DPTT }_{\mathrm{ti}} \quad=\text { Uneducated Employment of Agriculture } \\
& \text { sector (person/year) } \\
& \operatorname{DPTT}_{(\mathrm{t}-1) \mathrm{i}}=\operatorname{Lag}_{\operatorname{DPTT}_{\mathrm{ti}}} \\
& \text { GDPPti = Gross Domestic Product of Agricultural } \\
& \text { Sector (Billion / year) } \\
& \text { GDPP }_{\mathrm{t}-1}=\text { Lag Gross Domestic Product of } \\
& \text { Agricultural Sector (Billion / Year) } \\
& \mathrm{p} \quad=\text { length of lag } \\
& \hat{\mathrm{I}} \mu_{\mathrm{t}}=\text { vector of residual }\left(\hat{I} \mu_{1 t, 2 t} \hat{I} \mu, \hat{I} \mu_{3 t}\right) \text { measuring } \mathrm{nx} 1
\end{aligned}
$$

The presence of integration based on the likelihood ratio test (LR). If the calculated value $\mathrm{LR}$ is greater than the critical value LR then we accept the existence of cointegration number of variables and vice versa if the calculated value LR is smaller than the critical value, then there is no cointegration. If there is cointegration, means that there are long-term relationships between variables and can be said both variables integrated. The relationship can be seen from the number cointegration and the size of the coefficient. If there is cointegration means that there is a long-term relationship among variables and may be said to GDP, educated and uneducated employment integrated. The relationship of integration can be seen from the number of cointegration happened and the size of the coefficient [5].

\section{RESULT AND DISCUSSION}

To maintain a high economic growth needed qualified and productive employment. Employment conditions in Indonesia was marked by the large number of workers in the agricultural sector whose productivity is relatively low, especially in the traditional agricultural sector compared with workers absorbed in non-agricultural sectors such as industry and services. Figure 1 presents a comparison between growth of GDP, educated and uneducated employment in the agricultural sector. The picture presents the interesting results that there is growth of educated employment is higher than economic growth in the agricultural sector, and vice versa uneducated employment growth was below the economic growth of agriculture sector. This indicates a positive for the development of agriculture sector in Indonesia that in the future the agriculture sector will begin to be dominated by educated employment. Thus, we need not worry with some of the view 
that the future agricultural sector will lost employment especially for educated employments.

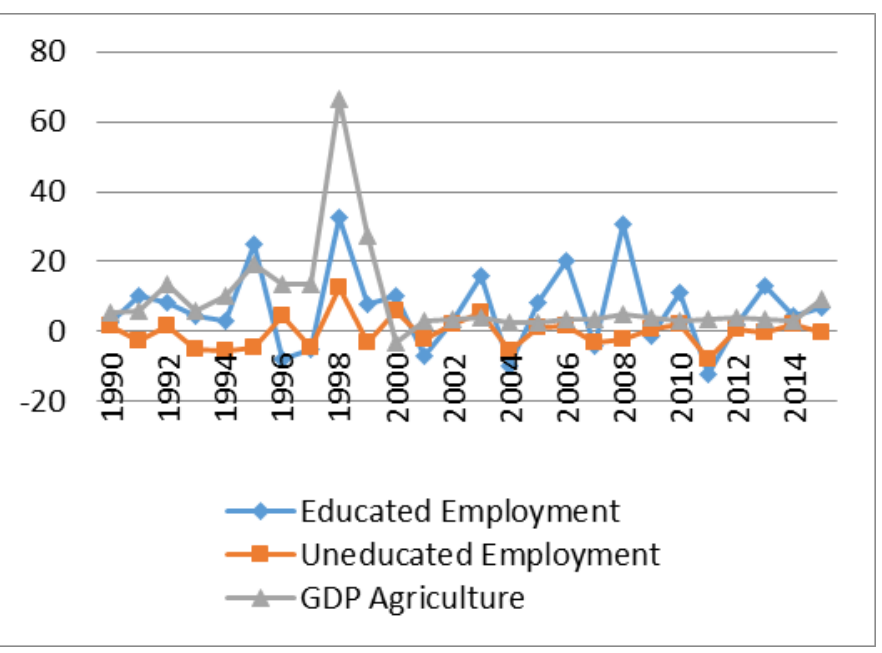

Figure 1. Comparison between GDP in goods market and educated- noneducated employment in the labor market at agriculture sector.

Market integration of goods markets and labor markets agricultural sector based educational perspective is a vertical market integration as seen through the balance of the amount of GDP and the number of educated and uneducated employment. Agriculture is the sector with un educated employment absorption is highest, but the contribution to the national production is lowest.

\section{Stationarity Test Data}

The unit root test conducted on three variables used in the model is the agricultural sector of educated workers (LOG DPTt), workers are not educated agricultural sector (LOG DPTTt), and the agricultural sector GDP (LOG GDPPt). According Widarjono (2007), if the time series has a unit root then the data is said to move randomly (random walk) and the data is said to have the nature of a random walk as the data is not stationary.

TABLE I. TEST FOR UNIT ROOT LEVEL

\begin{tabular}{|c|c|c|c|c|c|c|c|}
\hline \multirow{2}{*}{ Variable } & \multirow{2}{*}{ Lag } & \multirow{2}{*}{$t$-Statistic } & \multicolumn{3}{|c|}{ Test Critical Values } & \multirow{2}{*}{$\begin{array}{c}\text { Probabili } \\
\text { ty }\end{array}$} & \multirow{2}{*}{ Result } \\
\hline & & & $1 \%$ & $5 \%$ & $10 \%$ & & \\
\hline $\begin{array}{l}\text { LOG } \\
\text { DPT }\end{array}$ & 0 & -1.007 & -3.737 & -2.991 & -2.635 & 0.7336 & $\begin{array}{c}\text { Not } \\
\text { Stasion } \\
\text { er }\end{array}$ \\
\hline $\begin{array}{l}\text { LOG } \\
\text { DPTT }\end{array}$ & 1 & -1.701 & -3.752 & -2.998 & -2.638 & 0.4174 & $\begin{array}{c}\text { Not } \\
\text { Stasion } \\
\text { er }\end{array}$ \\
\hline $\begin{array}{c}\text { LOG } \\
\text { GDPP } \\
\end{array}$ & 0 & -2.131 & -3.737 & -2.991 & -2.635 & 0.2347 & $\begin{array}{c}\text { Not } \\
\text { Stasion } \\
\text { er } \\
\end{array}$ \\
\hline
\end{tabular}

Based on Table 1 shows that the level or I (0) it can be concluded that the data is not stationary. To make the data is not stationary, the data must be stationary by diffrence step. Table 2 shows that all variables, namely educated employments (LOG DPTt), educated employments (LOG DPTTt), and the GDP of the agricultural sector (LOG GDPPt) are not stationary at the current level but stationary on the first difference or I (1) and the level of the second diference or I (2). With the stasionernya data on difference step, then the analysis can be continued at the next step is testing to determine the optimal lag length.

TABLE II. UNIT ROOT TEST FOR DIFFERENCE

\begin{tabular}{|c|c|c|c|c|c|c|c|c|}
\hline \multirow{2}{*}{ Variable } & \multirow{2}{*}{ Lag } & \multirow{2}{*}{$t$-Statistic } & \multicolumn{3}{|c|}{ Test Critical Values } & \multirow{2}{*}{$\begin{array}{c}\text { Proba } \\
\text { bility }\end{array}$} & \multirow{2}{*}{ Difference } & \multirow{2}{*}{ Result } \\
\cline { 4 - 9 } & & & $1 \%$ & $5 \%$ & $10 \%$ & & \\
\hline LOG DPT & 0 & -6.817 & -3.752 & -2.998 & -2.638 & 0.000 & First & Stasioner \\
\hline LOG DPTT & 0 & -6.753 & -3.752 & -2.998 & -2.638 & 0.000 & First & Stasioner \\
\hline LOG GDPP & 1 & -5.6810 & -3.788 & -3.012 & -2.646 & 0.000 & Second & Stasioner \\
\hline
\end{tabular}

\section{Determination of Optimal Lag Level}

Determination of the long lag optimal use several criteria the following information: (1) Akaike Information Criterion(AIC), (2) Schwarrz Information Criterion (SC), (3) Likelihood Ratio (LR), and (4) The coefficient of determination ( $\mathrm{R}^{2)}$ as revealed Widarjono (2007).

Optimal lag candidate (indicated by asterisks) based on the criteria AIC, SC and $\mathrm{R}^{2}$ are at lag 3. Meanwhile, according to the criteria of the LR, the optimal lag is the lag 1. All testing was conducted at a 5 percent level of confidence (Table 3). So it can be concluded that the lag 3 is the optimal lag for integration model, where the results of analysis that uses lag VECM 3, the value of $\mathrm{R}^{2}$ obtained better.

TABLE III OPTIMAL LAG DETERMINATION FOR LABOUR MARKET INTEGRATION OF GOODS MARKETS IN AGRICULTURAL SECTOR PERSPECTIVE BASED ON EDUCATION IN INDONESIA

\begin{tabular}{|c|c|c|c|c|}
\hline Lag & LR & $\mathbf{R}^{2}$ & AIC & SC \\
\hline 1 & $157.99^{*}$ & 50.27 & -11.65 & -10.56 \\
\hline 2 & 163.04 & 70.81 & -11.82 & -10.69 \\
\hline 3 & 164.52 & $75.96^{*}$ & $-11.63^{*}$ & $-10.47^{*}$ \\
\hline
\end{tabular}

\section{Cointegration Analysis}

Cointegration test in this study conducted by Johansen test approach that is by comparing the trace statistic with critical value or by comparing the maximum eigenvalue with critical value used is 5 percent. If the trace statistic or maximum eigenvalue greater than the critical value, then there is cointegration in the equation system.

On the model of the goods market and the labor market, there are two linear equations in the long term (Table 4). Because there are two cointegration vectors (Vector Autoregression), the analysis of long-term cointegration vector can be specified for:

(1) GDP in agricultural sector. This is because the production of market goods produced by the agricultural sector is very low, so the number of qualified workers affected 
production in the agricultural sector of the labor market; and

(2) Educated employment in agricultural sector. This suggests that an increase in educated employment influenced by the ability of production in the market of goods and uneducated employment.

TABLE IV COINTEGRATION ANALYSIS FOR LABOUR MARKET INTEGRATION OF GOODS MARKETS IN AGRICULTURAL SECTOR BASED ON EDUCATION PERSPECTIVE IN INDONESIA

\begin{tabular}{|c|c|c|c|c|c|c|}
\hline \multirow{2}{*}{ Hypotesis } & \multicolumn{3}{|c|}{ Trace } & \multicolumn{3}{c|}{ Max-Eigenvalue } \\
\cline { 2 - 7 } & $\begin{array}{c}\text { Trace- } \\
\text { Stat }\end{array}$ & $\mathrm{CV}=5 \%$ & Prob $^{* *}$ & $\begin{array}{c}\text { Max- } \\
\text { Eigen } \\
\text { Stat }\end{array}$ & $\mathrm{CV}=5 \%$ & Prob $^{* *}$ \\
\hline None & $40.570^{*}$ & 29.797 & 0.002 & 23.303 & 21.131 & 0.024 \\
\hline At most 1 & $17.267 *$ & 15.494 & 0.026 & 15.716 & 14.264 & 0.029 \\
\hline At most 2 & 1.550 & 3.8414 & 0.213 & 1.5505 & 3.8414 & 0.213 \\
\hline
\end{tabular}

Trace test indicates 21 cointegrating eqn(s) at the 0.05 level

Max-eigenvalue test indicates 2 cointegrating eqn $(s)$ at the 0.05 level

* denotes rejection of the hypothesis at the 0.05 level

**MacKinnon-Haug-Michelis (1999) p-values

\section{VECM Analysis}

The existence of cointegration in models of labor market and goods market in agricultural sector could be interpreted that there is long-term equilibrium relationship between the variables observed. In the short term there may be an imbalance(disequilibrium). This imbalance requires an adjustment (adjustment). After the analysis shows that in the model there are two cointegration vector, we then analyzed VECM for times series data that are not stationary in levels, but stationary on diference and there is cointegration.

TABLE V. LONG RUN COINTEGRATION EQUATION FOR LABOUR MARKET INTEGRATION OF GOODS MARKETS IN AGRICULTURAL SECTOR BASED ON EDUCATION PERSPECTIVE IN INDONESIA

\begin{tabular}{lccc}
\hline Cointegration & \multicolumn{3}{c}{ Endogen Variable } \\
\cline { 2 - 4 } Equation $(C E)$ & Agriculture & Educated & Uneducated \\
& Production & Employment & Employment \\
& $($ LOG GDPP $)$ & $($ LOG DPT $)$ & $($ LOG DPTT $)$ \\
\hline CE1 & 1.000000 & 0.000000 & 31.23562[ \\
& & & $2.52766]^{* *}$ \\
\hline CE2 & 0.000000 & 1.000000 & 29.01975[ \\
& & & $2.74057]^{\star *}$ \\
\hline
\end{tabular}

NOTE: T-STATISTICS IN []; ** SIGNIFICANT PERCENT ON A 0.05

Table 5 presents the cointegration equation, which shows the long-term equilibrium relationship (LR) between the labor market and goods market agricultural sector in Indonesia, a real confidence level of 5 percent. This means that the development of the agricultural GDP is influenced by agricultural employments either educated or uneducated in Indonesia. In the long term is found (1) change of educated and uneducated employments will be transmitted in the agricultural sector GDP, (2) changes in educated employments and also to be transmitted on uneducated employments.
Results of this analysis indicate that the integration between the labor market and goods market agricultural sector in Indonesia does not happen perfectly. This integration imperfection actually is a good sign for the development of the agricultural sector. The GDP of agricultural sector integrated to educated and uneducated employments. Therefore, GDP is determined by the qualification of employments, then to pursue the improvement of quality of their GDP agricultural, then we should increase the number of educated employments in this sector. This is in line with previously stated thesis that the qualifications of workers determine the success of a agriculture sector. The better qualified employments, then the resulting production is better.

Table 6 shows the results of the coefficients of labor market integration and agricultural goods market in Indonesia. The coefficients Error Correction Term (ECT) describing the speed of adjustment towards equilibrium LR per period. ECT coefficient respectively for the labor market is larger than the coefficient ECT for goods market. Seen that the labor market more quickly than the goods market adjustment. Adjustment coefficients for uneducated employments are significant on level of 5 percent. This means that uneducated employments are will quickly respond to changing educated employments and agricultural GDP, but not vice versa. The rapid response of uneducated employments proves superfluous number of uneducated employments in the agricultural sector.

TABLE VI. COEFFICIENT VALUE OF VECM FOR LABOUR MARKET INTEGRATION OF GOODS MARKETS IN AGRICULTURAL SECTOR BASED ON EDUCATION PERSPECTIVE IN INDONESIA

\begin{tabular}{|c|c|c|c|c|c|c|}
\hline \multirow{2}{*}{$\begin{array}{l}\text { Error } \\
\text { Correction }\end{array}$} & \multicolumn{6}{|c|}{ Endogen Variable } \\
\hline & \multicolumn{2}{|c|}{$\begin{array}{l}\text { Agriculture Production } \\
\text { (LOG GDPP })\end{array}$} & \multicolumn{2}{|c|}{$\begin{array}{c}\text { Educated Employment } \\
\text { (LOG DPT) }\end{array}$} & \multicolumn{2}{|c|}{$\begin{array}{c}\text { Uneducated Employment } \\
\text { (LOG DPTT) }\end{array}$} \\
\hline ECT1 & -0.15117 & {$[-0.95382]$} & 0.199508 & {$[0.82076]$} & -0.222482 & {$[-3.649]^{* * *}$} \\
\hline ECT2 & 0.094969 & [0.52429] & -0.218184 & {$[-0.78541]$} & -0.285275 & {$[-4.094]^{* * *}$} \\
\hline $\begin{array}{c}\mathrm{D}(\mathrm{LOG} \\
\operatorname{GDPP}(-1)) \\
\end{array}$ & 0.210766 & [ 0.52842$]$ & 0.419132 & [ 1.68518$]^{*}$ & -0.206579 & {$[-1.3466]^{*}$} \\
\hline $\begin{array}{c}\mathrm{D}(\mathrm{LOG} \\
\mathrm{GDPP}(-2))\end{array}$ & 0.509139 & [ 1.4717]* & 0.065759 & [ 0.12394] & -0.121931 & {$[-0.91645]$} \\
\hline $\begin{array}{c}\text { D(LOG } \\
\text { GDPP(-3)) }\end{array}$ & 0.057970 & [ 0.17072] & -0.154120 & {$[-0.29595]$} & -0.162098 & {$[-1.24122]$} \\
\hline $\begin{array}{c}\text { D(LOG } \\
\text { DPT(-1)) }\end{array}$ & $\begin{array}{c}- \\
0.064565\end{array}$ & {$[-0.18053]$} & 0.404914 & [ 0.73821$]$ & -0.284565 & {$[-2.068]^{* *}$} \\
\hline $\begin{array}{c}\mathrm{D}(\mathrm{LOG} \\
\mathrm{DPT}(-2))\end{array}$ & 0.181746 & {$[-0.50924]$} & 0.184168 & [ 0.33647] & 0.139880 & [ 1.01907$]$ \\
\hline $\begin{array}{c}\text { D(LOG } \\
\text { DPT(-3)) }\end{array}$ & 0.189075 & [ 0.69206] & 0.062350 & [ 0.14881$]$ & 0.100807 & [ 0.95939$]$ \\
\hline $\begin{array}{c}\text { D(LOG } \\
\text { DPTT(-1)) }\end{array}$ & 1.596177 & [ 1.30354] & -1.215812 & {$[-1.6474]^{*}$} & 0.115519 & [ 0.24530$]$ \\
\hline $\begin{array}{c}\text { D(LOG } \\
\text { DPTT(-2)) }\end{array}$ & 1.896277 & [ 1.4792]* & -0.682575 & {$[-0.34718]$} & 0.299876 & [ 0.60823$]$ \\
\hline $\begin{array}{c}\text { D(LOG } \\
\text { DPTT(-3)) }\end{array}$ & 0.690114 & [ 0.6117$]$ & 0.205045 & [ 0.11851$]$ & 0.133546 & [ 0.30780$]$ \\
\hline $\mathrm{C}$ & 0.058554 & {$[1.881]^{* * *}$} & 0.023523 & {$[0.49266]$} & 0.005655 & {$[0.47226]$} \\
\hline $\mathrm{R}^{2}$ & 0.759536 & & 0.466931 & & 0.779977 & \\
\hline F-Statistic & 2.584331 & & 2.716669 & & 2.900433 & \\
\hline
\end{tabular}

NOTE: $:$ ECT $=$ ERROR CORRECTION TERM; $\quad \mathrm{D}(\mathrm{)})=$ FIRST DIFFERENCE OPERATORE; T-STATISTICS IN [ ] ; **SIGNIFICANT ON A : 0.05 PERCENT ; * SIGNIFICANT ON A : 0.10 PERCENT

GDP is influenced by the agricultural sector itself, namely the agricultural GDP in the lag 2, which give effect to the increase in GDP amounted to 0.509139. In addition, the GDP of the agricultural sector is also affected by uneducated employments with lag 2 , with the change of 1.896277 . The big influence of uneducated employments showed the high 
number of agricultural employments are not educated. As has been presented in Figure 1, although its continue to decline, but its share is still large.

Furthermore, Table 6 presents that educated employments are affected by the amount of lag of agricultural GDP with lag 1. Added GDP last year will have an impact on increasing the number of educated agricultural in the next year. This suggests that the increase in agricultural GDP has started aimed at establishment of educated employments. The one of important thing that uneducated employments are significantly negative effect for -1.215812 against the accretion of educated employments. This is linier with agrument that it has begun to shift the presence of educated workers in the agricultural sector. Reducing the number of uneducated employments will be substituted with the accretion of educated employments.

Interesting results found for the equation uneducated employments is influenced by the agricultural GDP in significantly negatively as much -0.206579 . This means an increase in the agricultural sector GDP will decrease the number of educated employments. This is in line with the result that most of the increase in agricultural GDP has been directed to the formation of educated employments. In addition, educated employments also significantly negatively influenced by the educated employments of -0.284565 . In the agricultural sector, employments are needed to assist in the production of agricultural commodities. Furthermore, if the demand for agricultural commodities increases with population growth, then the sector will increase demand for labor (Connell et al., 2006). Employment are derived demand, the strength of demand for some types of particularly labor will depend on: (1) how the productivity of workers in helping to produce products and services, and (2) the market value of the product or service (Swastika and Kustriari, 2000). These results are also consistent with the results of Sodik (2007), as well as Nurrohman danArifin (2010).

The overall results of this study demonstrate the integration that has been formed between the labor market and goods market in the agricultural sector shows a positive signal for the agricultural sector's ability to create jobs. It is the opposite of this outcome Adriani, D. and E. Wildayana (2014) where there is a negative signal between the goods market and the labor market. Labor as a factor of production already in the phase of decreasing returns to scale according toThe Law of Diminishing Returns introduced by David Ricardo. In theory, if the production process is in this phase, the use of these inputs are already excessive and should be reduced usage. It shows the the agricultural sector who work in the agricultural sector has been the excess of the absorption capacity of the agricultural sector.

These results more clearly show that if the analysis of employment studied in an educational perspective, we can see that the uneducated labor who work in the agricultural sector has been the excess of the absorption capacity of the agricultural sector, so its use should be reduced. But, educated employment who work in the agricultural sector is still below the absorption capacity of the agricultural sector, so that the use must be improved.

The results showed that Indonesia now and the next few years will continue to experience an imbalance in the short term. Although, we continue to pursue economic transformation, we still have to pay attention to the advantages of the agricultural labor force. Employment creation policies should still be continued, mainly to absorb surplus agricultural labor force through the industrialization of agriculture. Salah (2007) underlines that employment creation policy of this agricultural sector must be followed with the improvement of the quality of agricultural workers. Employment will be effective when coupled with policies to improve economic growth through increased investment and improved human capital. Investments can increase production capacity and improve the demand for labor, means to reduce unemployment. Improving the quality of human capital will improve production efficiency, thereby increasing the aggregate production and demand for labor, which means a decrease in the national unemployment rate.

\section{CONCLUSION AND POLICY RECOMMENDATION}

Growth in agricultural production is higher than the growth of employment both educated and uneducated. Growth in employment increased educated employments but decrease uneducated employments. The development of the agricultural GDP and educated employment is determined by uneducated employment in the agricultural sector. Imperfect integration occurs between the labor market and the agricultural sector market.

Diminishing uneducated employment, increasing the number of educated emplyments and decreasing agricultural GDP. Uneducated employment who work in the agricultural sector has been the excess of the absorption capacity of the agricultural sector, so its use should be reduced. But, educated employment who work in the agricultural sector is still below the absorption capacity of the agricultural sector, so that the use must be improved.

\section{ACKNOWLEDGMENT}

This article is part of a Fundamental research grant. Acknowledgements submitted to the Directorate General of Higher Education, Ministry of National Education, which has funded this study in accordance with the Implementation Agreement Assignment Sriwijaya University Fundamental Research Grant Number: 114 / UN9.3.1 / LT / 2015 dated March 5, 2015.

\section{REFERENCES}

[1] Abustan and Mahyuddin. 2009. Analysis of vector auto regressive (var) terhadapkorelasi between public expenditure and economic growth in south sulawesi, year 1985-2005. Journal of Development Economics Vol. 10, No.1: Page. 1-14

[2] Adriani, Dessy., And E. Wildayana. 2014. Goods market integration model analysis and labour market agricultural sector in indonesia: application error correction model. Research Report 2014. Grant 
Fundamental Research Institute of the University of Sriwijaya. Indralaya. Not published.

[3] Adriani, Dessy., And E. Wildayana. 2015. Integration of economic growth and creation of employment opportunities in the agricultural sector indonesia. Sosiohumaniora Journal Vol 17 (3) November 2015. In press.

[4] _ 1990-2014. National labour force survey. Central Bureau of Statistics. Jakarta.

[5] Ariani, Desi. 2012. Integration vertical market retail market producers rice with rice in indonesia. Technologist Management Journal Volume 11, Number 2: Page 225-238.

[6] Becker, Gary. 1995. Human capital and economic growth. PraugeEconomic-Papers Vol. 4 No. 3: 524-445.

[7] Birdsall, N., T. Pinckney, and R. Sabot. 2000. Natural resources, human capital and growth. Working Papers 9 February 2000. Global polic Program. Carnegie Endowment for International Peace.

[8] Connell, Champbell., SL Brue, and DA Macpherson. 2006. Contemporary labor economics. McGraw-Hill International Edition. Boston.

[9] DA Olaniyan and T. Okemakinde. 2008. Human capital theory: implications for educational development. European Journal of Science Research Vol 24, No. 2: 157-162. Http://www.eurojournal.com/ejrs.htm.

[10] Engle, RF and CWJ Granger. 1983. Cointegration and error correction: representation, estimation, and testing. Econometrica, 55: 251-276.

[11] Hilderbrand, V. 1995. Human capital development: a family objective. Overseas publishers association. Publishers BV Amsterdam under license by Gorogn ang Breach Science Publishers SA.

[12] Johansen, S. 1988. Statistical analysis of cointegration vectors. Journal of Economic Dynamics and Control 12: 231-234.

[13] Lucas, Robert E. Jr. 1988. On the mechanic of economic development. Journal of Monetary Economics 22: 4-42.

[14] Nurrohman, Riyadi and Arifin Zainal. 2010. Economic growth and analysis of project in Central Java Province. Journal of Development Economics, Vol 8 No. July 1st, 2010: Page 247 -260.

[15] Psacharopoulos, G. 1985. Returns to education: a further international update and implications. Journal of Human Resources 20 (4): pp. 583604.

[16] Psacharopoulos, George and HA Patrinos. 2004. Returns to investment in education: a further update. EducationEconomics, 12 (2): 111-34.

[17] Romer. 1996. Advanced macroeconomics. The McGraw-Hill Companies. Inc. New York.

[18] Ruby, DA 2003. Labor supply decisions economic and labor market equilibrium. Http: //www.digitaleeonomies.eom/Is 4020.html

[19] Sholeh, Maimonides. 2007. Demand and offers employment and wages: theory and some portraits in Indonesia. Journal of Economics and Education, Volume 4 No. 1: 62-75

[20] Siregar, H. 2006. Improved structure and economic growth: promoting investment and creating jobs. Business and Political Economy, Vol. 7 (2), April 2006 edition.

[21] Sodic, Jamzani. 2007. The government expenditure and regional economic growth: a case study panel data Indonesia. Journal of Development Economics, Vol 12 No. 1, April 2007: 27 - 36.

[22] Swastika, DK and R. Kustiari. 2000. Labor market dynamics, structure of wages, and prices in rural. Perspective Proceedings of Agriculture and Rural Development in an Era of Local Autonomy. Editor: IW Rusastra, AR Nurmanaf, SH Susilawati, Jamal E. and B. Sayaka (Editor). SocioEconomic Research Centre of Agriculture. Bogor.

[23] Todaro. 2000. Economic development in the third world. Translation. Interpretation : Aris in. Erland. Jakarta.

[24] Thomas, RL 1997. Modern econometrics: an introduction. AddisonWesley Longman Limited. Edinburg.

[25] Uzawa H. 1965. Technical change in aggregate optimal model of economic growth. International Economic Review No. 6: 18-31.

[26] Widarjono, Agus. 2007. Econometrics: theory and applications. Ekonisia. Yogyakarta. 